\title{
The Discussion of Scientific Application of Psychological Consult Skills in Universities Ideological and Political Education
}

\author{
Yunxue Si and Pumin Cai \\ School of Humanities and Laws, Tianjin Polytechnic University, Tianjin, China \\ si-yunxue@163.com
}

\begin{abstract}
With the development of higher universities ideological and political education, the subjective position of educatee is becoming more and more valued and respected. If we put humanism principle into effect, the educator must make innovation in education ways and skills, establish the idea of people-oriented, and also use the skills of listening, sharing and confrontation. In the process of education, the educator and educatee should have an equal communication in order to promote the harmonious development of education. Through the psychological consult, the universities can enhance their working effectiveness; promote the achievement of their working goals.

Index Terms - Psychological Consult, Skills, Higher Universities Ideological and Political Education, Application
\end{abstract}

\section{The Importance of Psychological Consult Skills in Higher Universities Ideological and Political Education}

The meaning of psychological consult is that consultants apply psychological theory and skills and with the help of languages and words to make communication and build some interpersonal relationship. It can help consulting person eliminate mental disorder, correctly know themselves and give full play of their proficiency. This can make them adapt the social environment effectively. Psychological consult includes the skills of listening, sharing and confrontation. It needs psychological consult deeply understand the consulting person's mind and personality characteristics, and then correct and guide them. Since 1980s, psychological consult has been introduced into ideological and political education as a working way. But as a branch of psychology, it has a material difference with ideological and political education. We cannot simply use it as a way; we should pay attention to its skills for reference in order to boost the development of ideological and political education, in the mean time to promote the construction of harmonious campus. As a result, we can achieve the goal to educate undergraduate and promote their free and comprehensive development.

\section{A. Promote the Human Perspective of Ideological and Political Education}

Ideological and political education means that society and social group use some thoughts, political ideas, moral criterion to give teleology, planed, organized effect to its social member, and then to make them form social practice which fit the society and class. The target of ideological and political education is man. Insisting ideological and political education is to make people form the moral character which fit and promote social development. Basically, ideological and political education studies how to educate people's mind. So it should study people, but not all aspects of people. The main study is people's thoughts, political view and moral qualities' shape, change and development. Thoughts, political view and moral qualities are all about society and man's relationship in behaviour standard. In order to deal with the relationship, we need to learn something about how to manage the relationship between men, because the nature of society is the total of all social relation. In order to achieve the goal, ideological and political education must build the concept of human, equally treat the educatee, and put the idea of people-oriented into practice. We must break in working methods. The working methods and skills of psychological consult set out from respecting and equally treating people. Studying the application method in ideological and political education has advantages in promoting the working method and idea in the development of humanization.

\section{B. Promote the Development of Ideological and Political Education Smoothly}

The main part of developing ideological and political education smoothly is the educatees. Educatees' personality and mind transition determine that education form must be improved and the education method must be changed with the times. With the rapid development of technology and the popularity of internet, the educator target has changed into the groups who have individuality and their own cultural characteristic. Because of the implement of population policy, the population of higher university is almost the only child. So their growing surroundings are superior, contacting things are more and more wide ranged, thinking issues are also more and more maturity. They not only have independent individuality, but also have interest in social subculture. Traditional ideological and political education methods cannot attract undergraduates' attention. Developing ideological and political education smoothly should grasp their personality and psychological characteristics. We should use flexible and infectious method to pass on knowledge to the students. Using psychological consult's principle of people-oriented, applying individuality-concerned treatment, enriching education method, and keeping up with trend can promote the smoothly development of higher universities ideological and political education [1]. 


\section{Promote the Construction of Higher Universities Harmonious Campus Culture}

It has three levels, including material form, system form and mind form in terms of campus culture form. Analyse the meaning of harmonious campus culture from these three levels, we can summarize the following six aspects: harmonious and perfect education environment; health and harmonious human relationship; reasonable allocation of all kinds of resource; rule systems of people-oriented; harmonious interactive between teachers and students; harmony and unity of universities' interest and the need of teachers and students' individuality. These basic connotations are our tasks and goals to construct the harmonious campus culture. And they are also specific operating platform. In order to achieve these goals, we must put psychology consult's skills into higher universities ideological and political education jobs. Because ideological and political education and harmonious campus culture has close relationship. The smoothly development of higher universities ideological and political education is one of the ways to construct harmonious campus culture. Harmonious campus culture construction can also provide support to the smoothly development of higher universities ideological and political education. Higher universities ideological and political educators grasp students' individuality demand, psychological character by means of grasping the listening, sharing and confrontation in the psychological consult, and then apply this new way to educational process. They should make educational content into new working ways in order to make student comprehend and receive educational content, and also to promote the harmonious campus culture construction.

\section{Promote the Cultivation of Undergraduates' Healthy Personality}

Contemporarily, undergraduates are in the condition of the end of adolescence and the beginning of adulthood, so their physiology and psychology are immature [1]. The undergraduates are easily influenced by the backward ideas, so they should improve their definition in social and international ideas and behaviours. In order to improve the cognitive resolution, we should use socialist core values systems to led undergraduates to form correct values. Fostering their healthy personality is one of higher universities ideological and political education goals. We need innovate the ways to achieve the goals. A series of psychological consult can help educators know students' feeling, and give them mildness and attention. It can promote the communication with students and to learn their feelings and thoughts. In this way, it can assist students' growing. Psychological consult's listening, sharing and confrontation can give guidance to undergraduates, help them establish their right views of life and values, and promote their own improvement and development.

\section{The Principle of Higher Universities Ideological and Political Education to Apply Psychological Consult Skills}

Since 1980s, higher universities ideological and political education has made psychological consult as an effect method to the field of working procedure. But in the specific application, it always has problems in psychological consult and ideological and political education. As a result, it influences the development between undergraduates' psychological consult and ideological and political education. They are not simply the affiliation and crossing relation, they also have coincident working goal, related working content and interactional function. However, they have differences in theoretical basis, working centrality, research model and working procedure. If higher universities ideological and political education wants to use psychological consult skills exactly, it must insist in these principles.

\section{A. Subsidiarity}

Psychological consult and higher universities ideological and political education belong to different subject, they not only have something same, but also have something different. The same reflects in that their studying and working target aims at people. Their purpose is designed to improve people's cognition and disposing capacity; adjust people's mood; increase people's enthusiasm. The difference is that the nature of higher universities ideological and political education is value intervention. It applies specific position, idea and method to reform students' world outlook, philosophy and value. The nature of psychological consult is function intervention. It applies psychological consult's theory, method and skills to help students know their psychological status, seek their psychological problems. Meanwhile it improves their personalistic healthy development by means of adjusting their cognition and behaviour [2]. Their common points decide that they do not repel each other. Their differences decide that they do not tolerate each other. Psychological consult makes group consult and individual consult which is based on people's mental occurrence and mental development regulation, and their individual mental characteristic. It is more specific than ideological and political education in solving people's psychological conflict and social adjustment problem. The reason is that the visitors are initiatively for help, thus it is more effectiveness. In these aspects, ideological and political education cannot tolerate or substitute. As a result, using listening, sharing and confrontation of psychological consult skills is the necessary supplement in higher universities psychological consult. It is the significant supplementary methods in higher universities ideological and political education.

\section{B. Education guidance principle}

The finial aim of psychological consult is to solve someone's mental healthy problem. It is based on individuality, and aims at to improve their adaptation ability and development. Higher universities ideological and political education is to solve students' development problem, at the same time to develop themselves in social moral behaviour guidance and universities' requirement. Consequently, it will promote consistency between individuality development and the requirement of higher universities' goals. Visually, higher universities ideological and political education and 
psychological consult are educational ways and means, so they both have educational meaning. Therefore, higher universities ideological and political education cannot simply emphasize individual mental adjustment when it uses psychological consult skills, because it will inevitably seek into the condition of self-centred. Higher universities ideological and political educator should listen attentively to students' experience and feelings, assist them to analyse advantages and disadvantages, exploit and turn thoughts, dredge unhealthy emotions and put forward right analysis opinion [3]. In this way, it can encourage them to properly treat their mental problems. And educator should also using socialist core values system to lead students to establish proper world outlook, philosophy and values; clear life goal; build lofty ideal.

\section{Characteristic principle}

Since the rise and development of psychological consult study and practice in the mid of 1980s, our psychological consult emphases importing, absorbing and digesting western psychological consult model. Nevertheless, western psychological consult theory and method is formed and developed from western historical culture, it adapts to westerners' mentality and personality characteristics. It cannot gain better effect in our higher universities ideological and political education. Thus higher universities ideological and political educator must base on our national conditions and cultural characteristics, undergraduates' mental characteristic, influence factor and universities' reality to combine education content and consult skills [4]. As a result, it can catch students' imagination. Higher universities are special community and students are in the critical period of mind and body development, so with the development of physiology and psychology, the increasing of competitive pressure, spread of social practice, the change of thinking mode, they can have problems in study, life, interpersonal communication and selfconsciousness. Hence, we must use psychological consult skills based on students' characteristics in order to promote progressive of higher universities ideological and political education, and propel the achievement of educating goal.

\section{The Application of Psychological Consult Skills in Higher Universities Ideological and Political Education}

With the transition of the times, undergraduates' mind and mental characteristics also changed. In order to carry out ideological and political education successfully, we must innovate educator method. Because of the consistency in higher universities ideological and political education working goals, study targets and psychological consult, it has necessary reference in the field of working method. The application of listening, sharing and confrontation skills in higher universities ideological and political education can have advantages in achieving working goals, and promoting its effectiveness.

\section{A. The Scientific Application of Listening Skill}

The listening skill is different from the common communication. It requires consultants to listen to the opposite side carefully, identity their inner experience, accept their way of thinking, reflect and feedback in their position. In higher universities ideological and political education, better listening is the premise to achieve effect communication between teachers and students, and it is also the basic requirement to build better relationship with each other. Teachers need to listen to their students' statements seriously, inspire them continuously, and make students show their own ideas and feelings. In this way, it can not only let students feel respected, but also let teachers know their true psychological states. Listening students' statements effectively can help ideological and political educators fully understand their thoughts and find their mind problem [5]. Meanwhile, it can let students feel that they are concerned, respected and valued by educators. Therefore, they will have trust and intimacy with educators. As a result, it can promote the progressive of ideological and political education.

\section{B. The Scientific Application of Sharing Skill}

Sharing skill also means the same feeling, it indicates that consultants can sharply and properly know visitors' meaning and feeling, and transfer these comprehensions to visitors [5]. In higher universities ideological and political education, sharing means that educators put themselves into students' mentality and feeling. Sharing contributes to help build trustful, equal, valued and harmonious relation between educators and students. It is essential condition to make educational jobs successfully. In higher universities ideological and political education, if educators want to accomplish sharing skill, they need to adopt comprehensive opinions, and not make any moral evaluation and judgments. They should have the abilities to sufficiently realize students' feelings, beliefs and attitudes from the procedure of observation and listening. Remarkably, sharing skill is not let educators fully give up the right values, but temporarily throw off the traditional criteria, approach into students' inner world, know the root of problems, and finally solve their problems via scientific methods. At the same time, they should use advanced socialist culture to lead students build proper and positive world outlook, philosophy and values.

\section{The Scientific Application of Confrontation Skill}

Confrontation skill is an important technology to change visitors in psychological consult. It is the procedure of consultants to challenge and suggest visitors' cognitive style and thinking method. The purpose and meaning of confrontation is to give assistance to help visitors to know their idea, feeling, behaviour, the situation, and settle all disorders, self-contradiction, different words and deeds, feelings. Using confrontation skill should base on facts in higher universities ideological and political education. The foundation of confrontation is fact. When fact is insufficiency and inconspicuous, we cannot apply this method. When undergraduates have differences in actual self and ideal self, imaginary world and real world, thought cognitive and behaviour, higher universities ideological and political educators can apply face-to-face confrontation skill. They can base on the fact to have relatively guidance by knowing the 
students' mental problems [6]. Educators need to encourage students to bravely face their true inner feelings, rationally analyse the relationship between surroundings and their own cognitive behaviour, and help them understand themselves. Finally, educators make students find a right way to achieve their ideal, and promote the unification of ideal self and real self.

\section{References}

[1] R. Suleiman, D. V. Budescu, I. Fischer, and D. M. Messick, Contemporary psychological research on social dilemmas, Cambridge University Press, 2004, pp.66.
[2] K. Hogan, and J. Speakman, Covert Persuasion: Psychological Tactics and Tricks to Win the Game, Wiley, 2004, pp.28.

[3] Q. Luo, "Cognition and Countermeasures of contemporary college students on college psychological counseling," Northern Economy and Trade, vol. 3, pp. 143-45, 2012

[4] L. Lin, "Localization of psychological counseling in the ideological and political education use,"Contemporary Theory and Practice, vol. 4, no. 2, pp. 48-49, February 2012.

[5] Q. Zhang, "Psychological counseling sessions in the ideological and political education," Jilin Education, vol. 5, no. 13, pp. 113-114, 2009.

[6] F. Fan, The theory and practice of group counseling - University of psychological counseling and education guide books, Beijing: Tsinghua UniversityPress,2004,pp.26 